\title{
Effect of Growth Medium and Nutrient Solution on Phytochemical and Nutritional Characteristics of Strawberry (Fragaria $\mathrm{x}$ ananassaDuch.)
}

\author{
Robabeh Asghari ${ }^{1}$ \\ ${ }^{1}$ Institute of Applied Scientific Higher Education of Jahad-e Agriculture, Imam Khomeini Agricultural Higher \\ Education Center, Karaj, Iran
}

Correspondence: Robabeh Asghari, Institute of Applied Scientific Higher Education of Jahad-e Agriculture, Imam Khomeini Agricultural Higher Education Center, Karaj, Iran. Tel: 93-5239-4098. E-mail: fariba2022@yahoo.com

Received: May 19, 2014 Accepted: June 8, 2014 Online Published: July 15, 2014

doi:10.5539/jas.v6n8p52 URL: http://dx.doi.org/10.5539/jas.v6n8p52

\begin{abstract}
Strawberries are an important fruits because of their high content of essential nutrients and beneficial phytochemicals. This study was conducted to evaluate the effect of soilless culture growing media on biochemical characteristics (TSS, TA, vitamin $\mathrm{C}$, anthocyanin and $\mathrm{pH}$ ) of strawberry cultivar Gavieta. The experiment was carried out in a factorial base on randomized complete design with three replications Results of this experiment showed that almost the best percentage of biochemical characteristics of fruits was observed in vermicompost + perlite + cocopeat (30:60:10) without chemical fertilizer treatment. Based on the experiment, pruning waste can be useful for producing good strawberry taste and increasing.
\end{abstract}

Keywords: strawberry, growth medium, phytochemical, pruning waste, anthyoxidant

\section{Introduction}

The strawberry (Fragaria $\mathrm{x}$ ananassaDuch.) is an important fruit with considerable natural source of bioactive compounds because of its high levels of vitamin C, folate, and phenolic components (Proteggente et al., 2002; Scalzo, 2005), most of which show antioxidant potential in vitro and in vivo (Scalzo \& Mezzetti, 2005; Scalzo \& Politi, 2005; Tulipani et al., 2009; Wang et al., 2000). To a lesser extent, strawberries are a source of healthy, essential fatty acids, because its seed oil is rich in unsaturated fatty acids. The fruit is also rich in manganese, potassium, iodine, magnesium, copper, iron, and phosphorus. Besides these nutritive compounds, strawberries contain a variety of non-nutritive components such as polyphenolic phytochemicals (Francesca et al., 2012). Moreover, strawberries are economically and commercially important and widely consumed fresh or in processed forms, such as jams, juices, and jellies. That is why they are among the most studied berries from the agronomic, genetic, and nutritional points of view.

Fruit's aroma and taste is the result of a special assortment and mixture of different metabolites. While sugars and acids contribute to sweetness and tartness, aroma is derived from combinations of volatile molecules. The different proportions of the volatile components and the presence or absence of trace components often determine aroma properties (Ayala-Zavala et al., 2004).

Because of increased demand for more products with high quality and offseason, greenhouse productions are increasing. The soil acts as a reservoir to retain nutrients and water, and also provides physical support for the root system. Soilless culture is an artificial means of providing plants with support and a reservoir for nutrients and water. Characteristics of media include holding water and nutrient, providing good aeration to root system, light weight, free of pathogens and substances that are toxic to plants (Johnson et al., 2010). Using different organic and inorganic media allows the plants better nutrient uptake, sufficient growth and development to optimize water and oxygen holding (Albaho et al., 2009). Choosing the medium should be based on its physical characteristics as well as availability and cost (Lieten et al., 2004). Strawberries are grown under glass or polyethylene-covered greenhouses, including micro or macro tunnels, using a variety of growing containers and soilless media.

The influence of several pre- and postharvest factors on the phytochemical and nutritional composition of strawberry is already known (Tulipani et al., 2008). The properties of different materials used as growing media 
exhibit direct and indirect effects on plant growth and productivity. Some technical and economic factors play significant role when choosing media. First of all gravel or sand, then materials such as peat, vermiculite and perlite have been used commonly (Ercisli, 2005). Coconut coir is also an inexpensive soilless media, it has been characterized in terms of physical properties with good water retention capacity and aeration (Noguera et al., 2003), and has performed better as compared to other media in ornamental crops (Aniel et al., 2007; Abad et al., 2002). Vermicompost consists of available forms of nutrition for plant uptake such as nitrates, exchangeable phosphorus, potassium, calcium and magnesium; known as a medium that is one of the effective factors in plant growth and yield (Cantliffe, 2007), so that Sahin stated that perhaps the most important factor in production of greenhouse crops is the type of medium used (Sahin, 2005). Vermicompost, in contrast to conventional compost is the product of an accelerated biooxydation of organic matter by the use of high densities of earthworm populations without passing a thermophilic stage (Domy et al., 1997; Reinikainen, 1993). Vermicompost is an environmentally acceptable means for convert waste to nutritious compost (Singh et al., 2010). Desirable growth of plant was appeared with vermicompost application (Melgar-Ramirez and Pascual-Alex, 2010). Vermicomposts contain growth-regulating materials, such as plant growth hormones and humic acids. According reports it caused increasing germination, growth and yields of plants (Arancon et al., 2004). Application of vermicompost as horticultural media usually enhanced seedling growth and development and productivity of a wide variety of crops (Edwards et al., 2004). vermicompost as soil amendment and as plant growth media due to having high porosity, good aeration, drainage, water-holding capacity and very high microbial activity (Atiyeh et al., 2000) is one of the medium which can be used as a replacement for peat and composted pruning waste. Advantages of using of compost included reduction of volume of waste and high potential for using as growth medium (Benito et al., 2006). Pathogens or trace metals present in composts can have hazardous effects. Analysis of materials studied demonstrated that composting of pruning waste which its organic components are free of contaminated waste, leads to a high quality organic amendment (Benito et al., 2006). Experiments were done on silage corn as a crop demonstrated that sugarcane compost as a composted planting waste has sufficient to nearly sufficient from most nutrients elements but has limitations in supporting some nutrients elements so its deficiency can be recovered via adding the chemical fertilization (Bruce, 2007).

The objective of this experiment was to assess the function of different growing media with different ratio of perlite, coco peat, vermicompost and golja (golja is an organic fertilizer based on composed waste that is enriched by supporting some nutritional elements) on phytochemical and nutritional indexes of strawberry cultivar Gavieta.

\section{Method}

\subsection{Plant Preparation}

The study was carried out in March to August, 2013, at an experimental greenhouse of the plant production department, Imam Khomeini higher educational center Karaj, Iran. The experiment was in factorial based randomized complete design with three replications. Experimental treatment consisted of one strawberry cultivar Gavieta and six growing media with different ratio of growing media in two groups, with and without Nutrient Solution:

Table 1. Growth medium compound used for different treatments

\begin{tabular}{lc}
\hline Growing Media & Nutrient Solution \\
\hline G1 $=60 \%$ perlite and $40 \%$ coco peat & + \\
G $1=60 \%$ perlite and $40 \%$ coco peat & - \\
G2 $=60 \%$ perlite, $10 \%$ coco peat and $30 \%$ vermicompost & + \\
G $2=60 \%$ perlite, $10 \%$ coco peat and $30 \%$ vermicompost & - \\
G3 $=60 \%$ perlite, $10 \%$ coco peat and $30 \%$ golja (composted sugar & + \\
cane waste + mineral element) & \\
G $3=60 \%$ perlite, $10 \%$ coco peat and $30 \%$ golja (composted sugar & - \\
cane waste + mineral element) & + \\
G4 $=60 \%$ perlite, $10 \%$ coco peat, $15 \%$ vermicompost and $15 \%$ golja & + \\
G $4=60 \%$ perlite, $10 \%$ coco peat, $15 \%$ vermicompost and $15 \%$ golja & - \\
\hline
\end{tabular}




\begin{tabular}{ll}
\hline G5 $=60 \%$ perlite, $10 \%$ coco peat, $10 \%$ vermicompost and $20 \%$ golja & + \\
G $5=60 \%$ perlite, $10 \%$ coco peat, $10 \%$ vermicompost and $20 \%$ golja & - \\
G6 $6=60 \%$ perlite, $10 \%$ coco peat, $20 \%$ vermicompost and $10 \%$ golja & + \\
G $6=60 \%$ perlite, $10 \%$ coco peat, $20 \%$ vermicompost and $10 \%$ golja & - \\
\hline
\end{tabular}

Day/night temperature was kept at $22 / 17{ }^{\circ} \mathrm{C}$ respectively. Growth media were prepared based on volume (the volume of a pot was $2000 \mathrm{~cm}^{3}$ ). Three plants were planted in each pot. Nutrient solution formula for the group containing chemical treatment wasprepared according to Kerej et al. (1999) instruction. The pH and EC of nutrient solution were adjusted to 5.7 and 0.9 to $1.4 \mathrm{dS} \mathrm{m}^{-1}$, respectively. Measured fruit properties were total soluble solids (TSS), total acidity (TA), vitamin C, anthocyanin and $\mathrm{pH}$.

Nutrient solution formula for the group containing chemical treatment was used as stock; that is: $1800 \mathrm{~g} \mathrm{KH}_{2} \mathrm{PO}_{4}$, $1000 \mathrm{~g} \mathrm{KNO}_{3}, 3200 \mathrm{~g} \mathrm{Ca}\left(\mathrm{NO}_{3}\right)_{2} \cdot 4 \mathrm{H}_{2} \mathrm{O}, 800 \mathrm{~g} \mathrm{MgSO}_{4} \cdot 7 \mathrm{H}_{2} \mathrm{O}$ and $400 \mathrm{~g} \mathrm{~K}_{2} \mathrm{SO}_{4}$ were dissolved in 5000 liters of water. Elements' amount was the same in different solutions which contained $50 \mathrm{~g} \mathrm{H}_{3} \mathrm{BO}_{3}, 70 \mathrm{~g} \mathrm{MnSO}_{4}, 60 \mathrm{~g}$ $\mathrm{ZnSO}_{4}, 10 \mathrm{~g} \mathrm{CuSO}_{4}$ and $2 \mathrm{~g} \mathrm{H}_{2} \mathrm{Moo}_{4}$. These were dissolved in 5000 liters of water. To provide iron, $180 \mathrm{Fe}-\mathrm{EDTA}$ (iron clot) was solved in 5000 liters of water (Arzani, 2007).

\subsection{Determination of Total Anthocyanin Content (ACY)}

The ACY of the extracts was determined using a changed $\mathrm{pH}$ differential method previously described (Giusti and Wrolstad (2001), Absorbance readings were converted to quantifications through a calibration curve, obtained from known concentrations of pelargonidin-3-glucoside (Pg-3-gluc) standards. Results are expressed as milligrams of Pg-3-gluc equivalents per gram of FW of strawberry. Data are reported as a mean value (SD for six measurements (Tulipani et al., 2008).

Total soluble solids (TSS), total titratable acidity (TA), and $\mathrm{pH}$ determinations:

Twenty fruits from each replicate were wrapped in cheesecloth and squeezed with a hand press, and the juice was analyzed for TSSs, $\mathrm{pH}$, and TA. TSSs were determined at $20^{\circ} \mathrm{C}$ on an Atago DBX-55 refractometer. $\mathrm{pH}$ was measured with a $\mathrm{pH}$ meter. TA was determined by diluting each $5 \mathrm{ml}$ aliquot of strawberry juice in $95 \mathrm{ml}$ of distilled water and then titrating to $\mathrm{pH} 8.2$ using $0.1 \mathrm{~mol} \mathrm{~L}^{-1} \mathrm{NaOH}$ (MacNaeidhe, 1999; AOAC., 2000).

\subsection{Determination of Vitamin $C$}

HPLC determination of vitamin C content ascorbic acid was measured as described by Helsper (Helsper, 2003) briefly. Vitamin $\mathrm{C}$ was extracted by sonication of $0.5 \mathrm{~g}$ of wet frozen powder in $2 \mathrm{ml}$. of ice coldwater with 5\% metaphosphoric acid and $1 \mathrm{mM}$ DTPA, followed by centrifugation at $2500 \mathrm{rpm}$ for $10 \mathrm{~min}$, filtering, and immediate analysis on an HPLC system. Quantification was made through a standard calibration curve prepared by running standard concentrations of vitamin $\mathrm{C}$ prepared similarly and measured in duplicate at the beginning and end of the analysis. As for folate determination, the intracultivar biological variability was assessed by separate samplings of strawberries for two of the genotypes. Results are expressed as milligrams of vitamin C per gram of FW (SD for biological variability) (Tulipani et al., 2008).

\section{Result}

Considering the study results showed growing medium with different rate of vermicompost and golja effect significantly on soluble solids and anthocyanin $(\mathrm{p}<0.01)$ and on vitamin $\mathrm{C}(\mathrm{p}<0.05)$, however did not observed significant effect on total acidity and medium $\mathrm{pH}$. Adding chemical treatment to the medium exposed significant effects on all regarded parameters of fruit $(\mathrm{p}<0.01)$ except on vitamin that did not observed significant effect (Table 2).

Interaction percentages of different substrates and chemical treatment showed significant effect on TSS, anthocyanin and $\mathrm{pH}(\mathrm{p}<0.01)$ (Table 1).

Using different media and chemical treatment together increased the strawberries total soluble solids, total acidity and $\mathrm{pH}$, but decreased their vitamin $\mathrm{C}$ and anthocyanin content. Growth media were used did not show influence on vitamin $\mathrm{C}$ but changed the others certain characters (Table 3) 
Table 2. Analysis of variance for strawberry (cv. Gavieta) phytochemical characters under different treatments

\begin{tabular}{|c|c|c|c|c|c|c|}
\hline & & & Phytochemical & Characters & & \\
\hline Treatment & $\mathrm{df}$ & TSS (Brix) & $\begin{array}{c}\text { TA } \\
\left(\mathrm{mg} / 100 \mathrm{gF} . \mathrm{W}_{.}\right)\end{array}$ & $\begin{array}{c}\text { Vitamin C } \\
\text { (mg/gF.W.) }\end{array}$ & $\begin{array}{c}\text { Anthocyanin } \\
\text { (mg/100gF.W.) }\end{array}$ & pH \\
\hline Nutrient Solution & 5 & $12.117 * *$ & $0.0064 * *$ & $0.031 \mathrm{~ns}$ & $9638145.9^{* *}$ & $0.071 * *$ \\
\hline Growth medium & 1 & $10.028 * *$ & $0.0001 \mathrm{~ns}$ & $0.201^{*}$ & $25831806.3^{* *}$ & $0.007 \mathrm{~ns}$ \\
\hline Nutrient $_{\mathrm{S}} *$ Growth $_{M}$ & 5 & $22.561 * *$ & $0.0019 \mathrm{~ns}$ & $0.041 \mathrm{~ns}$ & $10976179.1 * *$ & $0.096^{* *}$ \\
\hline Error & 24 & 2.388 & 0.0008 & 0.053 & 472120.639 & 0.003 \\
\hline $\mathbf{C V}$ & & 13.4 & 11.3 & 23.2 & 9.1 & 1.5 \\
\hline
\end{tabular}

$*=\mathrm{P}<0.05, * *=\mathrm{P}<0.01, \mathrm{~ns}=$ not significant.

Table 3. Effect of growth medium and nutrient solution interaction on strawberry (cv.Gavieta) phytochemical characters

\begin{tabular}{|c|c|c|c|c|c|c|}
\hline \multirow[b]{2}{*}{ Growth medium } & \multicolumn{6}{|c|}{ PhythochemicalCharacters } \\
\hline & \multicolumn{2}{|c|}{ TSS (Brix) } & \multirow{2}{*}{$\begin{array}{c}\begin{array}{c}\text { TA } \\
(\mathrm{mg} / \mathbf{1 0 0 g F} . W .)\end{array} \\
0.18 \mathrm{e}\end{array}$} & \multirow{2}{*}{$\begin{array}{c}\begin{array}{c}\text { Vitamin C } \\
\text { (mg/gF.W.) }\end{array} \\
1.07 \mathrm{ab}\end{array}$} & \multirow{2}{*}{$\begin{array}{c}\begin{array}{c}\text { Anthocyanin } \\
(\mathbf{m g} / \mathbf{1 0 0 g F} . W .)\end{array} \\
6203.1 \mathrm{a}\end{array}$} & \multirow{2}{*}{$\begin{array}{c}\mathbf{p H} \\
3.89 \mathrm{a}\end{array}$} \\
\hline $\mathrm{D} 60+\mathrm{C} 40$ & Chemo.0 & $9.67 b$ & & & & \\
\hline טד & Chemo.1 & $10.67 \mathrm{~b}$ & $0.21 \mathrm{de}$ & $0.97 \mathrm{ab}$ & $422.0 \mathrm{e}$ & $3.92 b$ \\
\hline \multirow{2}{*}{$\mathrm{P} 60+\mathrm{C} 10+\mathrm{V} 30$} & Chemo.0 & $15.33 \mathrm{a}$ & $0.25 b c$ & $1.30 \mathrm{a}$ & $4549.0 \mathrm{~b}$ & $3.91 b$ \\
\hline & Chemo.1 & $10.67 \mathrm{~b}$ & $0.27 \mathrm{ab}$ & $0.93 \mathrm{ab}$ & $440.3 \mathrm{e}$ & $3.56 f$ \\
\hline \multirow{2}{*}{$\mathrm{P} 60+\mathrm{C} 10+\mathrm{G} 30$} & Chemo.0 & $10.00 \mathrm{~b}$ & $0.25 \mathrm{bc}$ & $0.97 \mathrm{ab}$ & $2756.3 \mathrm{~cd}$ & $3.53 \mathrm{f}$ \\
\hline & Chemo.1 & $10.67 \mathrm{~b}$ & $0.23 \mathrm{~cd}$ & $0.97 \mathrm{ab}$ & $1515.7 \mathrm{de}$ & $3.74 d$ \\
\hline \multirow{2}{*}{$\mathrm{P} 60+\mathrm{C} 10+\mathrm{V} 15+\mathrm{G} 15$} & Chemo.0 & $10.67 \mathrm{~b}$ & $0.26 \mathrm{ab}$ & $1.07 \mathrm{ab}$ & $2550.0 \mathrm{~cd}$ & $3.78 \mathrm{~cd}$ \\
\hline & Chemo.1 & $16.01 \mathrm{a}$ & $0.22 \mathrm{de}$ & $1.00 \mathrm{ab}$ & $2067.3 \mathrm{~cd}$ & $4.08 \mathrm{a}$ \\
\hline \multirow{2}{*}{$\mathrm{P} 60+\mathrm{C} 10+\mathrm{V} 10+\mathrm{G} 20$} & Chemo.0 & $8.65 b$ & $0.23 \mathrm{~cd}$ & $1.00 \mathrm{ab}$ & $5375.7 \mathrm{ab}$ & $3.79 \mathrm{~cd}$ \\
\hline & Chemo.1 & $14.02 \mathrm{a}$ & $0.29 \mathrm{ab}$ & $1.00 \mathrm{ab}$ & $5513.7 \mathrm{ab}$ & $3.63 \mathrm{ef}$ \\
\hline \multirow{2}{*}{$\mathrm{P} 60+\mathrm{C} 10+\mathrm{V} 20+\mathrm{G} 10$} & Chemo.0 & $11.12 b$ & $0.31 \mathrm{a}$ & $1.07 \mathrm{ab}$ & $1653.7 \mathrm{de}$ & $3.87 \mathrm{bc}$ \\
\hline & Chemo.1 & $9.66 \mathrm{~b}$ & $0.28 \mathrm{ab}$ & $0.73 b$ & $2963.7 \mathrm{c}$ & $3.70 \mathrm{de}$ \\
\hline
\end{tabular}

Among the fruits that were produced in different growth media, fruits produced in a medium with equal percentage of vermicompost (15\%) and golja (15\%) plus $10 \%$ cocopeat and $60 \%$ perlite, had highest content of TSS, and $\mathrm{pH}$. However in medium with lower percent of vermicompost (10\%) and golja (20\%) plus perlite (60\%) and cocopeat $(10 \%)$ had the highest level of anthocyanin against with $20 \%$ vermicompost and $10 \%$ golja plus $10 \%$ cocopeat and $60 \%$ perlite that had the highest acidity were detectable. Therefore vermicompost plus an organic amendments, such as traditional thermophilic composts, showed positive effect on fruit characters that influence fruits taste, aroma and quality and also their nutritional value. However vermicompost (30\%) lonely had similar effect on the characters but its effect is a little lower. Therefore the effect of different organic media on the fruit phytochmistry was not equal. A medium with sufficient percentages of components supply best conditions for producing fruits with higher that index. In this study strawberries growth in the medium with $30 \%$ vermicompost, $10 \%$ cocopeat and $60 \%$ perlite can provide the best conditions and adding golja to the medium did not show any effect. The strawberries growth in a medium that used golja 30\% instead of vermicompost, the characters appeared in lower level (Tables 3 and 4). 
Table 4. Effect of nutrient solutionon on strawberry (cv.Gavieta) phytochemical characters

\begin{tabular}{cccccc}
\hline \multirow{2}{*}{ Nutrient Solution } & \multicolumn{5}{c}{ Phythochemical } \\
\cline { 2 - 6 } & TSS(Brix) & TA(mg/100gF.W.) & Vitamin C (mg/gF.W.) & Anthocyanin (mg/100gF.W.) & pH \\
\hline Chemo.0 & $11.89 \mathrm{~b}$ & $0.25 \mathrm{a}$ & $1.08 \mathrm{a}$ & 3847.9 & $3.79 \mathrm{a}$ \\
Chemo.1 & $11.94 \mathrm{a}$ & $0.25 \mathrm{a}$ & $0.93 \mathrm{~b}$ & $2153.8 \mathrm{~b}$ & $3.77 \mathrm{a}$ \\
\hline
\end{tabular}

Table 5. Effect of growth mediumon on strawberry (cv.Gavieta) phytochemical characters

\begin{tabular}{cccccc}
\hline & \multicolumn{5}{c}{ Phythochemical Characters } \\
\cline { 2 - 6 } Growth medium & TSS(Brix) & $\begin{array}{c}\text { TA } \\
(\mathbf{m g} / \mathbf{1 0 0 g F} \text {.W. })\end{array}$ & $\begin{array}{c}\text { Vitamin C } \\
(\mathbf{m g} / \mathbf{g F} . W .)\end{array}$ & $\begin{array}{c}\text { Anthocyanin } \\
(\mathbf{m g} / \mathbf{1 0 0 g F} . W .)\end{array}$ & $\mathbf{p H}$ \\
\hline P60+C40 & $10.17 \mathrm{c}$ & $0.20 \mathrm{c}$ & $1.02 \mathrm{a}$ & $3312.5 \mathrm{~b}$ & $3.89 \mathrm{a}$ \\
P60+C10+V30 & $13.00 \mathrm{ab}$ & $0.26 \mathrm{~b}$ & $1.12 \mathrm{a}$ & $2494.7 \mathrm{bc}$ & $3.74 \mathrm{~b}$ \\
P60+C10+G30 & $10.33 \mathrm{c}$ & $0.24 \mathrm{~b}$ & $0.97 \mathrm{a}$ & $2136.0 \mathrm{c}$ & $3.64 \mathrm{c}$ \\
$\mathrm{P} 60+\mathrm{C} 10+\mathrm{V} 15+\mathrm{G} 15$ & $13.33 \mathrm{a}$ & $0.24 \mathrm{~b}$ & $1.03 \mathrm{a}$ & $2308.7 \mathrm{c}$ & $3.92 \mathrm{a}$ \\
$\mathrm{P} 60+\mathrm{C} 10+\mathrm{V} 10+\mathrm{G} 20$ & $11.33 \mathrm{bc}$ & $0.26 \mathrm{~b}$ & $1.01 \mathrm{a}$ & $5444.7 \mathrm{a}$ & $3.71 \mathrm{~b}$ \\
$\mathrm{P} 60+\mathrm{C} 10+\mathrm{V} 20+\mathrm{G} 10$ & $10.33 \mathrm{c}$ & $0.30 \mathrm{a}$ & $0.90 \mathrm{a}$ & $2308.7 \mathrm{c}$ & $3.78 \mathrm{~b}$ \\
\hline
\end{tabular}

\section{Discussion}

High sugar and relatively high acid content are required for good strawberry flavor (Kader, 1990). Although not all strawberries with high TSSs are high quality, unlikely the absence of high TSSs makes good quality. Galletta et al., (1995) reported that TSSs in strawberries generally ranged between $7-12 \%$ depending on genotype. Fructose and glucose were found to be the two major sugars in strawberry fruit comprising more than $65 \%$ of the TSS (Wangand Camp, 2000).

Based on previous study it was indicated that vermicompost contains most nutrients in plant-available forms such as nitrates, phosphates, exchangeable calcium and soluble potassium (Aniel et al., 2007; Abad et al., 2002; Cantliffe et al., 2007a; Singh et al., 2010). Substitution of small amounts of vermicomposts into soilless bedding-plant potting mixtures, has resulted in significant increases in the germination and growth of marigolds, tomatoes and peppers, in greenhouse trials, when all necessary nutrients are available, even at substitution rates as low as 5-30\%, into the medium (Atiyeh et al., 2000a, 2000b, 2002a; Melgar-Ramirez \& Pascual- Alwx, 2010).

Tulipani et al. (2008) reported that strawberries grown in greenhouses with a variety of soilless growing media revealed the impact of the phytochemical and nutritional composition. Melgar- Ramirez and Pascual-Alex (2010) also reported that the $\mathrm{EC}, \mathrm{pH}$, bulk density and water soluble elements related to media increased with increasing amounts of vermicompost in the media, whereas significantly decreased the total porosity, availability of water and total water holding capacity. The growth of tomato seedlings in $10 \%$ vermicompost (from pig waste) substrate significantly increases compared with those of plants grown in 100\% Metro-Mix 360, 100\% peat/perlite mixture or $100 \%$ coir/perlite mixture (Atiyeh et al., 2000b). Zaller (2007) used percentage of vermicompost in substrate as substitute for peat, and the results of his experiment showed that biomass allocation (root: shoot ratio), morphological and chemical fruit parameters were significantly affected by seedling substrate. However, it has not affected on yield and marketability of tomato. Zaller (2007) suggested vermicompost as an environmentally friendly potting media.

The result of present study provided enough reason for positive impact of vermicompost on improving the fruit index than the other nutritional characteristics. However when growing medium contains sufficient percentage of it; you must add the other nutrients for preparing best soilless growing medium and getting fruits with acceptable indexes.

Adding chemical fertilizer to the different growth mediums showed negative result. When we used $30 \%$ vermicompost plus chemichal fertilizer, fruit characters were influenced negatively, but when chemical fertilizer was added to medium with $15 \%$ or $10 \%$ vermicompost , the treatment showed positive effect on certain characters of strawberry, whereas when vermicompost content in growth medium have been increased $(20 \%)$ adding chemical fertilizer exposed negative effect on the characters (Table 3). So if growth organic medium was used to 
provide optimum nutritional factor, chemical treatments effect will be negative. As was explained before, growing medium with sufficient ratio of vermicompost did not need to be improved by adding an organic or inorganic fertilizer. It can supply enough nutritional material for plant growing with the highest quality (flavor aroma, taste and appearance).

\section{References}

Abad, M., Noguera, P., Puchades, R., Maquieira, A., \& Noguera, V. (2002). Physicochemical and chemical properties of some coconut coir dusts forusin gas apeat substitute forcontainerized ornamental plants.Bioresource Technology, 82, 241-245. http://dx.doi.org/10.1016/S0960-8524(01)00189-4

Albaho, M., Bhat, N., Abo-Rezq, H., \& Thomas, B. (2009). Effect of Three Different Substrateson Growth and Yield of Two Cultivars. Europe Journal of Science Reserch, 28(2), 227-233.

Ameri, A., Tehranifar, A., Shoor, M., \& Davarynejad, G. H. (2012). Effect of substrateand Cultivar on Growth Characteristic of Strawberry in Soilless Culture System. African Journal of Biotechnology, 11(56), 11960-11966.

Aniel, J., Cantliffe, J. Z., Astellanos, C., \& Paranjpe, A. V. (2007). Yield and Quality of Greenhouse-grown Strawberries asAffected by NLevel in Coco Coir and Pine Bark Media. Proceeding of the Florida State Horticulture Society, 120, 157-161.

AOAC. (2000). Official method of analysis (17 $7^{\text {th }}$ Ed.). Gaithersburg, MD, USA: Association of Official Analytical Chemists, No. 967.21, Ascorbic acid in vitamin preparation and juices.

Arancon, N. Q., Edwards, C. A., Atiyeh, R., \& Metzger, J. D. (2004). Effects of vermicompost sproduced from food waste on the growth andyields of greenhouse peppers. Bioresource Technology, Tomatoes, 75, 175-180.

Arzani, M. (2007). Cultivation without soil (Hydroponic), commercial and house-made. Isfahan Industrial Press. First Publication.

Atiyeh, R. M., Arancon, N., Edwards, C. A., \& Metzger, J. D. (2000a). Influence of earthworm-processed pigmanure on the growth and yield of greenhouse tomatoes. Bioresource Technology, 75, 175-180. http://dx.doi.org/10.1016/S0960-8524(00)00064-X

Atiyeh, R. M., Edwards, C. A., Subler, S., \& Metzger, J. D. (2000b). Earthworm processed organic wastes as components of horticultural potting media for growing marigold sand vegetable seedlings. Compost Science Utilization, 8, 215-233. http://dx.doi.org/10.1080/1065657X.2000.10701994

Atiyeh, R. M., Lee, S., Edwards, C. A., Arancon, N. Q., \& Metzger, J. D. (2002). The influence of humic acids derived from earthworms processed organic wastes on plant growth. Bioresource Technology, 84, 7-14. http://dx.doi.org/10.1016/S0960-8524(02)00017-2

Ayala-Zavala, J. F., Shiow, Y., Wang, C. Y., Wang, G. A., \& Aguilar, G. (2004). Effect of storage temperature son antioxidant capacity and aroma compounds in strawberry fruit. Lebensmittel Wissenschaft Technology, 37, 687-695.

Benito, M., Masaguer, A., Moliner, A., \& DeAntonio, R. (2006). Chemical and physical properties of pruning waste compost and their seasonal variability. Bioresouce Technololog, 97, 2071-2076. http://dx.doi.org/10.1016/j.biortech.2005.09.011

Bruce, W., Mathews, J., \& Cynthia, J. (2007). Evaluation of a Compost Derived from Sugarcane Processing. By-Products College of Agriculture, Forestry, and Natural Resource Management.University of Hawai' $i$ at Hilo, Hilo, HI 96720-4091.

Cantliffe, D. J., Castellanos, J. Z., \& Paranjpe, A. V. (2007a). Yield and Quality of Greenhouse-grown Strawberries as Affected by Nitrogen Level in Coco Coir and Pine Bark Media. Proceeding of the Florida State Horticulture Society, 120, 157-161.

Cantliffe, D. J., Paranjpe, A. V., Stoffella, P. J., Lamb, E. M., \& Powell, C. A. (2007b). Influence of Soilless Media, Growing Containers and plug transplants influence on vegetative growth and fruit yield of 'Sweet Charlie' strawberry ( Fragaria $\times$ ananassaDuch.) grown under protected agriculture. Proceeding of the Florida State Horticulture Society, 120, 142-150.

Domýn'nguez, J., Edwards, C. A., \& Subler, S. (1997). A comparison of vermicomposting and composting methods to process animal wastes. Biocycle, 38, 57-59. 
Edwards, C. A., \& Arancon, N. Q. (2004). The Use of earthworms in the breakdown oftheorganic wastes to produce vermicompostsand animal feed protein. In C. A. Edwards (Ed.), Earthworm Ecology (pp. 345-438). Boca Raton, FL: CRC Press. http://dx.doi.org/10.1201/9781420039719

Ercisli, S., Sahin, U., Esitken, A., \& Anapali, O. (2005). Effects of some growing media on the growth of strawberry cvs. 'Camarosa' and 'Fern'. ACTA Agrobotanica, 58, z.1s.185191.

Galletta, G. J., Maas, J. L., Enns, J. M., Draper, A. D., \& Swartz, H. J. (1995). 'Mohawk' strawberry. Horticultureal Science, 30, 631-634.

Giampieri, F., Tulipani, S., Alvarez-Suarez, J., Quiles, J. L., Mezzetti, B., \& Battino, M. (2012). The strawberry: Composition, nutritional quality, and impact on human health. Nutrition, 28, 9-19. http://dx.doi.org/10.1016/j.nut.2011.08.009

Giusti, M. M., \& Wrolstad, R. E. (2001). Characterization and measurement of anthocyanins by UV-visible spectroscopy. Curr. Protocols Food Anal. Chem.

Helsper, J. P. F. G., de Vos, C. H. R., Maas, F. M., Jonker, H. H., van den Broeck, H. C., Jordi, W., ... Schapendonk, A. H. C. M. (2003). Response of selected antioxidants and pigments in tissues of Rosa hybrida and Fuchsia hybrida to supplemental UV-A exposure. Physiology Plantarum, 117, 171-187. http://dx.doi.org/10.1034/j.1399-3054.2003.00037.x

Johnson, J. R. H., Hochmuth, G. J., \& Maynard, D. N. (2010). Soilless Cultureof Greenhouse Vegetables. Institute of Food and Agricultural Sciences. University of Florida, 218, 19-22.

Kader, A. A. (1990). Quality and its maintenance to the postharvest physiology of strawberry. In A. Dale \& J. J. Luby (Ed.), Proceedings of the third NorthAmerican strawberry conference (pp. 145-152). Houston. Portland, OR: Timber Press.

Kerej, C., Voogt, W., \& Bass, R. (1999). Nutrition solution and water quality for soilless cultures. Brochure of research station for floriculture and glasshouse vegetables.

Lieten, F., Longuesserre, J., Baruzzi, G., Lopezmedina, J., Navatel, J. C., Krueger, E., Matala, V., \& Paroussi, G. (2004). Recent situation of strawberry substrate culture in Europe. Acta Horticulture, 649, 193-196.

Mac Naeidhe, F. S. (1999). The Effect of Nutrition on the Flavour of Strawberries Grown under Protection. Soft Fruit and Beekeeping Research Centre.

Melgar-Ramirez, R., \& Pascual-Alex, M. I. (2010). Characterization and use of a vegetable waste vermicompost as an alternative component in substrates for horticultural seedbeds. Spanish Journal Agriculture Research, 8(4), 1174-1182. http://dx.doi.org/10.5424/sjar/2010084-1407

Noguera, P., Abad, M., Puchades, R., Maquieira, A., \& Noguera, V. (2003). Influence of particles izeon physicaland chemical properties of coco nut coir dust as containe rmedium. Communication Soil Science Plant Analysis, 34, 593-605. http://dx.doi.org/10.1081/CSS-120017842

Proteggente, A. R., Pannala, A. S., Paganga, G., VanBuren, L., Wagner, E., Wiseman, S., ... Rice-Evans, C. A. (2002). The antioxidant activity of regular consumed fruit and vegetables reflects their phenolic and vitamin C composition. Free Radical Research, 36, 217-233. http://dx.doi.org/10.1080/10715760290006484

Reinikainen, O. (1993). Choice of growing media for potplants. Acta Horticulturae, 342, 357-360.

Sahin, U., Ors, S., Ercisli, S., Napaliand, O. A., \& Esitken, A. (2005). Effect of pumice amendment on physical soil properties and strawberry plant growth. Journal Central European Agriculture, 6(3), 361-366.

Scalzo, J., Mezzetti, B., \& Battino, M. (2005). Total antioxidant evaluation: critical steps for assaying berry antioxidant features Biofactors, 23, 221-227. http://dx.doi.org/10.1002/biof.5520230407

Scalzo, J., oliti, A., Pellegrini, N., Mezzetti, B., \& Battino, M. (2005). Plant genotype affects total antioxidant capacity and phenolic contents in fruit. Nutrition, 21, 207-213. http://dx.doi.org/10.1016/j.nut.2004.03.025

Singh, R. Gupta, R. K., Patil, R. T., Sharma, R. R., Asrey, R., Kumarand, A., \& Jangra, K. K. (2010). Sequential foliar application of vermicompost leachates improves marketable fruit yield and quality of strawberry $\begin{array}{lllll}\text { (Fragaria } \times \text { ananassaDuch.). } & \text { Scientia } & \text { Horticulturae, } & \text { 34-39. }\end{array}$ http://dx.doi.org/10.1016/j.scienta.2009.12.002

Tulipani, S., Mezzetti, B., \& Battino, M. (2009). Impact of strawberries on human health:insight into marginally discussed bioactive compounds for the Mediterranean diet. Public Health Nutrition, 12(9A), 1656-1662. http://dx.doi.org/10.1017/S1368980009990516 
Tulipani, S., Mezzetti, B., Capocasa, F., Bompare, S., \& Beekwilder, J. (2008). Antioxidants, Phenolic Compounds, and Nutritional Quality of Different Strawberry Genotypes. Journal Agriculture Food Chemical, 56, 696-704. http://dx.doi.org/10.1021/jf0719959

Tulipani, S., Romandini, S., Alvarez Suarez J. M., Capocasa, F., Mezzetti, B., \& Busco, F. (2008). Folate content in different strawberry genotypes and folate status in healthy subjects after strawberry consumption. Biofactors, 34(1), 47-55. http://dx.doi.org/10.1002/biof.5520340106

USDA National Nutrient Database for Standard ReferenceAgriculture Research Service. (2010). Release 23, Fruits and fruit juices, pp. 7-785.

Wang, S. Y., \& Camp, M. J. (2000). Temperatures afterbloomaffect plant growth and fruit quality of strawberry. Scientia Horticulture, 85, 183-199. http://dx.doi.org/10.1016/S0304-4238(99)00143-0

Wang, S. Y., \& Lin, H. S. (2000). Antioxidant activity in fruits and leaves of blackberry, raspberry, and strawberry varies with cultivar and developmental stage. Journal of Agriculture Food Chemical, 48, 140-146. http://dx.doi.org/10.1021/jf9908345

Zaller, J. G. (2007). Vermicompostasa substitute for peat in potting media:effects on germination, biomass all ocation, yields and fruit quality of three tomato varieties. Science Horticultureal, 112, 191-199. http://dx.doi.org/10.1016/j.scienta.2006.12.023

\section{Copyrights}

Copyright for this article is retained by the author(s), with first publication rights granted to the journal.

This is an open-access article distributed under the terms and conditions of the Creative Commons Attribution license (http://creativecommons.org/licenses/by/3.0/). 